\title{
Effect of Different Fermentation Time on the Microbial, Mineral and Proximate Composition of Parkia biglobosa Seeds Fermented for Iru Production
}

\author{
Atere Ayowole V.", Oyetayo Victor. O and Akinyosoye Felix A. \\ Depatrment of Microbiology, Federal University of Technology, Akure, P.M.B 704 Akure, Nigeria \\ *e-mail: victor_efosa001@yahoo.com, ovonew@gmail.com, felixkinsola@yahoo.com
}

Keywords: Effect, Fermentation, Nutritional Iru, Bacillus subtilis, Parkia biglobosa

\begin{abstract}
Fermented food condiments form an integral part of African diets as they supply nutrients with claimed medicinal properties. This research was designed to investigate the effect of period of fermentation on the microbial, mineral and proximate composition of fermented Parkia biglobosa seeds. The bacteriological, nutritional and sensory parameters were carried out on the raw, dehulled and fermented seeds. The result of the total bacterial counts showed that the raw seed had $3.67 \log _{10} \mathrm{cfu}$, there was a significant increase in the total bacteria count from $2.20 \log _{10} \mathrm{cfu} / \mathrm{g}$ in dehulled unfermented bean to $9.248 \log _{10} \mathrm{cfu} / \mathrm{g}$ at $96 \mathrm{~h}$ of fermentation. The bacteria isolated were Bacillus subtilis (32 isolates), Lactobacillus plantarum (9 isolates), and Leuconostoc spp (3 isolates). The $\mathrm{pH}$ increased significantly from 4.57 in the raw seeds to 8.40 at $96 \mathrm{~h}$ of fermentation. The titratable acidity decreased from $0.179 \mathrm{~N}$ in the raw seeds until it got to $0.0313 \mathrm{~N}$ at $96 \mathrm{~h}$ of fermentation. The proximate composition on dry mass basis showed that 'iru' fermented for $48 \mathrm{~h}$ had the highest protein content of $41.023 \%$. The carbohydrate decreased from $42.153 \%$ in the raw seed to $20.733 \%$ at the end of fermentation. Four of the minerals; lead, cadmium, cobalt and nickel were detected in the raw seeds but were no longer available after dehulling. Phosphorus, sodium, calcium and potassium increased during the fermentation period. The sensory result showed that the intensity of growth on the surface of the fermenting bean increased. Moreover, the sensory score on the texture showed that the seed became softer as the fermentation progressed. The colour became darker and the ammonia odour became more pungent. The overall-liking showed a significant increase as the fermentation progressed where the panelist preferred the product fermented for $72 \mathrm{~h}$. The result from this study revealed that the best time for fermentation of Parkia biglobosa seeds to produce good quality 'iru' was between $48 \mathrm{~h}$ and $72 \mathrm{~h}$.
\end{abstract}

\section{Introduction}

Fermented foods have a long tradition, they have been produced in order to extend the shelflife of raw materials and increase their safety. In their production, microorganisms play a vital and essential role, contributing to the improvement of the physiochemical, sensory and safety characteristics of the final products [1]. Many familiar foods and beverages such as yoghurt, cheese, beer and soy sauce are fermented. Often the fermentation not only imparts a pleasant taste but can also increase the nutritional value of a food; and act as a preservative. In African countries, cereals account for as much as $77 \%$ of total caloric consumption and contribute substantially to the dietary protein intake. Majority of traditional foods consumed in Africa are processed by natural fermentation [2]. For example, 'Garri' is a Nigerian fermented carbohydrate food sourced from fermented cassava [3].

Iru is an African soup condiment obtained from the fermentation of the seeds of Parkia biglobosa. Generally, foods and condiments are fermented to improve the nutritional quality, enhance the safety as well as creating variety [4]. In Africa, Parkia biglobosa seeds are seen as a major source of protein. The protein content has been reported to be as high as $40 \%$ which is slightly higher than that of other legumes [5]. Parkia biglobosa is traditionally fermented to produce 'iru'. Researchers have reported the nutritional composition, biochemical changes and microbial load of fermented Parkia biglobosa seeds to produce 'iru' $[1,4,5,6,7,8,10,12,15,16]$. However, little information 
has been documented on the changes in the nutritional quality of the seeds during the period of fermentation of Parkia biglobosa seeds. It is therefore imperative that different period of fermentation be studied in order to know the best time that can give the best 'iru' in terms of proximate, microbial, mineral and sensory qualities. Therefore, this research was designed to determine the nutritional quality of seeds of Parkia biglobosa fermented for different periods.

\section{Methodology}

\section{Source of Materials}

The African locust bean seeds (Parkia biglobosa) were purchased from a local market (Oja Oba) in Omuo- Ekiti, Ekiti State, Nigeria.

\section{Production of Iru}

Iru was produced in the laboratory by fermenting the seeds of Parkia biglobosa. The Parkia biglobosa seeds were soaked in the water for 30 mins and cooked under pressure for $2 \mathrm{~h}$. The cooked seeds were dehulled and the washed cotyledons were re-cooked for $1 \mathrm{~h}$. The excess water was drained and poured into fermenters and were fermented for $24 \mathrm{~h}, 48 \mathrm{~h}, 72 \mathrm{~h}$ and $98 \mathrm{~h}$ respectively.

\section{Microbial Analysis}

Standard microbial procedure as documented by Osho et al. [6] was used in determining the microbial load and identity of the Bacterial isolates. The bacterial isolates were identified based on their cultural, morphological and biochemical characteristics.

\section{Determination of physicochemical parameters}

The $\mathrm{pH}$, titratable acidity, proximate and mineral composition were determined based on the AOAC [7] standard.

\section{Determination of sensory Attributes of Samples.}

Ten grams $(10 \mathrm{~g})$ of the sample was taken into 30 containers each and were examined by 30 different panelist. The five point Hedonic scoring scale was used by the panelist in determining the intensity of bacterial film growth, texture, colour, ammonia odour and overall liking of the fermented samples. Table 1 shows parameter and grading used for the sensory evaluation.

Table 1: Sensory parameters used in evaluation of samples

\begin{tabular}{|c|c|c|c|c|c|}
\hline Parameter & 1 & 2 & 3 & 4 & 5 \\
\hline $\begin{array}{l}\text { Intensity of } \\
\text { Growth }\end{array}$ & No Growth & Traces & Slight & Moderate & Very Much \\
\hline $\begin{array}{l}\text { Texture (w.r.t } \\
\text { unfermented) }\end{array}$ & $\begin{array}{l}\text { Slightly } \\
\text { harder }\end{array}$ & $\begin{array}{l}\text { Neither } \\
\text { softer nor } \\
\text { harder }\end{array}$ & $\begin{array}{l}\text { Slightly } \\
\text { softer }\end{array}$ & $\begin{array}{c}\text { Moderately } \\
\text { softer }\end{array}$ & $\begin{array}{l}\text { Very much } \\
\text { softer }\end{array}$ \\
\hline $\begin{array}{l}\text { Colour (w.r.t. } \\
\text { unfermented) }\end{array}$ & Much darker & $\begin{array}{l}\text { Slightly } \\
\text { darker }\end{array}$ & No change & $\begin{array}{l}\text { Slightly } \\
\text { lighter }\end{array}$ & Much lighter \\
\hline $\begin{array}{l}\text { Ammonia } \\
\text { odour }\end{array}$ & Very Strong & High level & Moderate & Slight/ trace & Absent \\
\hline Overall-liking & $\begin{array}{l}\text { Dislike very } \\
\text { much }\end{array}$ & $\begin{array}{l}\text { Dislike } \\
\text { slightly }\end{array}$ & $\begin{array}{l}\text { Neither like } \\
\text { nor dislike }\end{array}$ & Like slightly & $\begin{array}{l}\text { Like very } \\
\text { much }\end{array}$ \\
\hline
\end{tabular}

\section{Statistical Analysis}

The data collected were subjected to analysis of variance (ANOVA) and means separated with Duncan's Multiple Range Test (DMRT) using Statistical Package for Social Sciences (SPSS version $16.02010)$. 


\section{Results}

The bacterial load of the fermented Parkia biglobosa seeds increased significantly from $2.20 \log \mathrm{cfu} / \mathrm{g}$ at the beginning of the fermentation to $9.24 \log _{10} \mathrm{cfu} / \mathrm{g}$ at $96 \mathrm{~h}$ of fermentation (Figure 1). The $\mathrm{pH}$ increased significantly throughout the fermentation period while the titratable acidity decreased as shown in Figures 2 and 3 respectively. The proximate composition of the samples showed that protein increased significantly from the onset of fermentation till $48 \mathrm{~h}$ and later decreased. The highest protein was recorded after fermenting for $48 \mathrm{~h}$ (Table 2). Table 3 shows the mineral composition of the fermented seeds where there was increase in sodium, potassium, magnesium and iron. The organoleptic evaluation of the samples was presented in Figure 4, there was increase in growth intensity, softness, colour and ammonia odour as the fermentation progressed, however, the overall liking increased and drops after $72 \mathrm{~h}$ of fermentation.

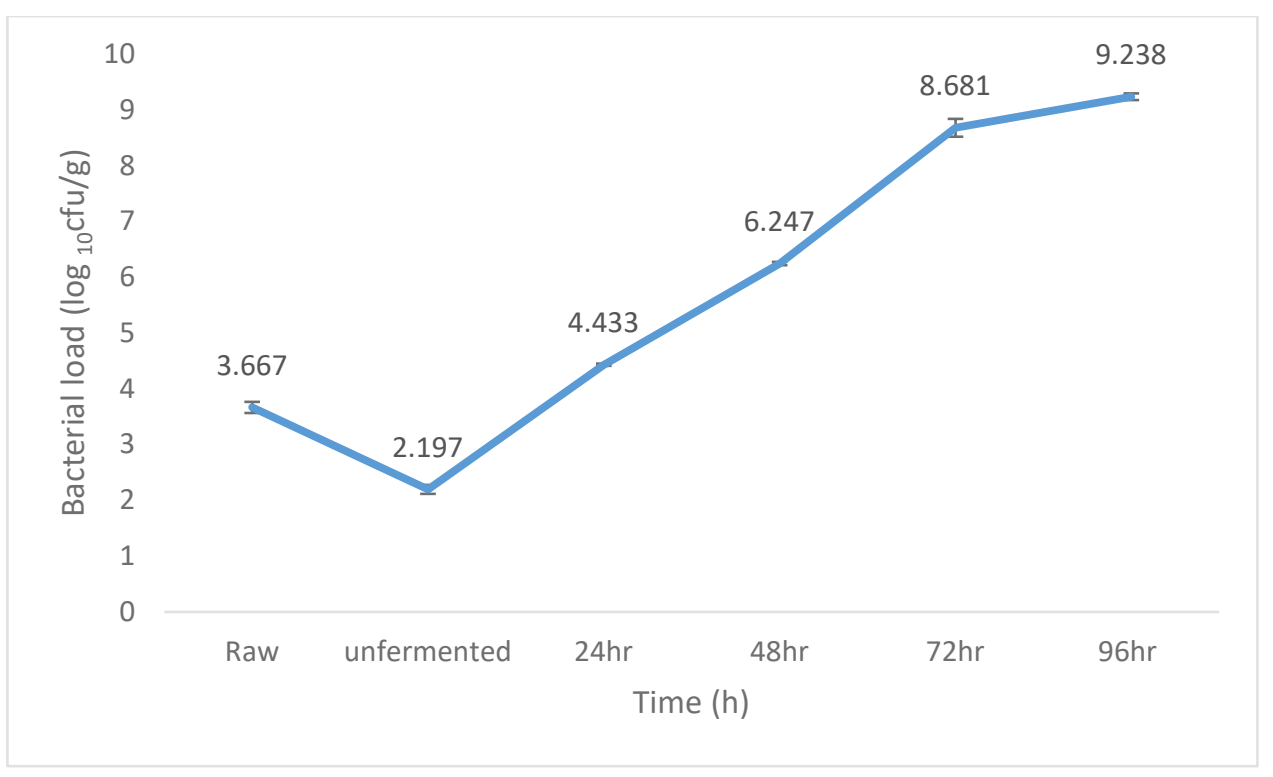

Figure 1: Bacterial load $\left(\log _{10} \mathrm{cfu} / \mathrm{g}\right)$ of Parkia biglobosa seeds during spontaneous fermentation

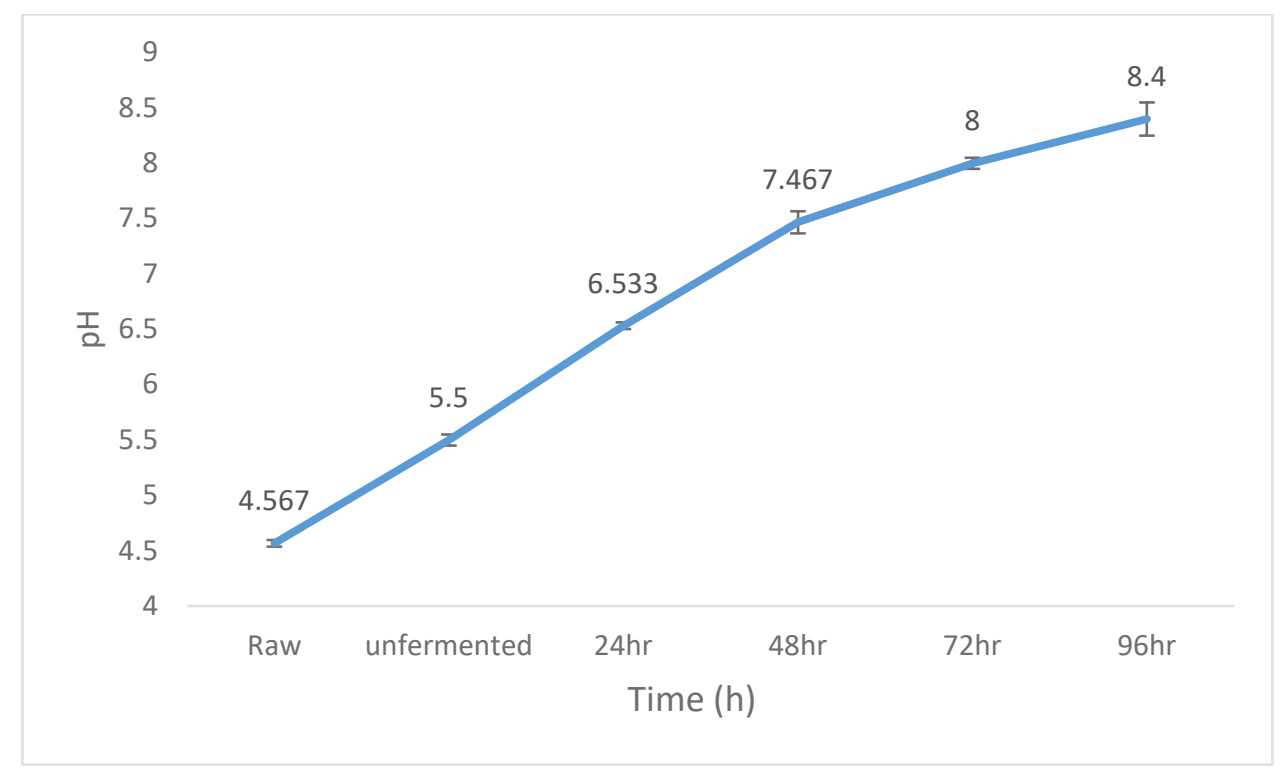

Figure 2: The $\mathrm{pH}$ of Parkia biglobosa seeds before and during fermentation 


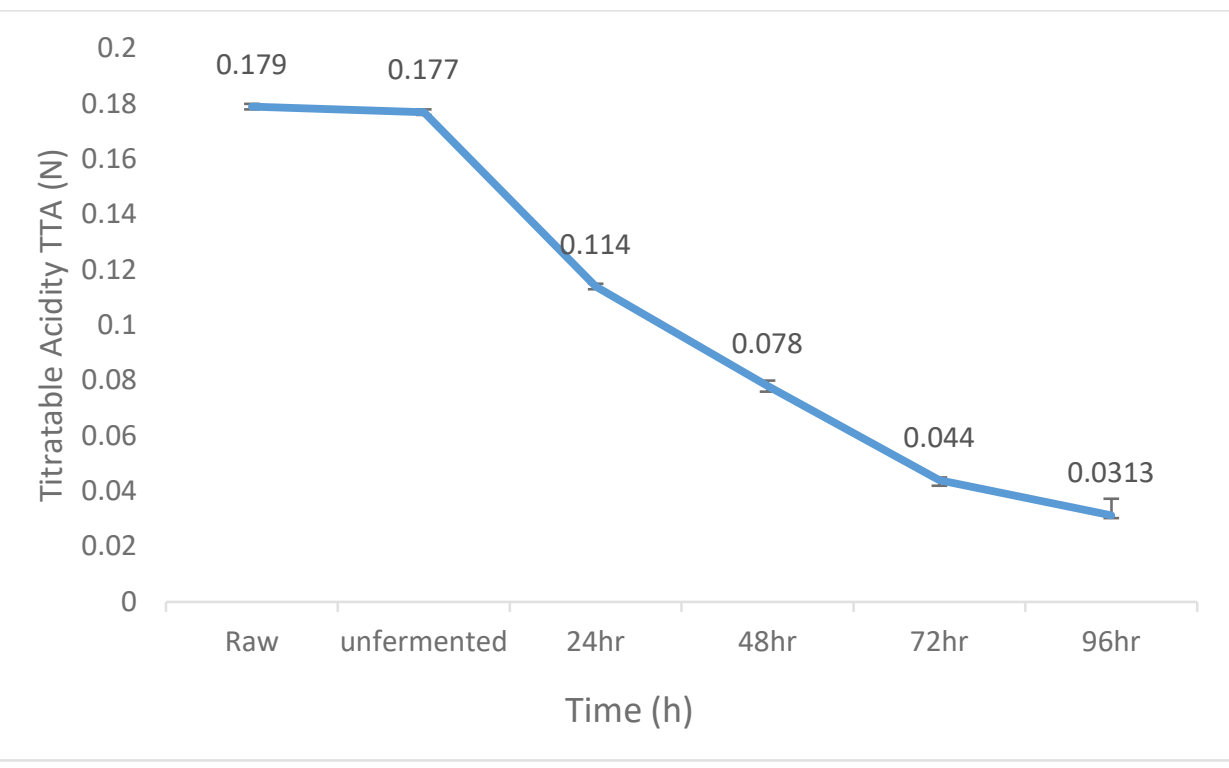

Figure 3: Titratable Acidity TTA (N) of Parkia biglobosa seeds before and during fermentation

Table 2: The proximate composition (\%) of raw and fermented Parkia biglobosa seeds

\begin{tabular}{|l|l|l|l|l|l|l|}
\hline Samples & Ash & Carbohydrate & Crude Fat & Fibre & Moisture & Protein \\
\hline Raw seed & $4.527 \pm 0.15^{\mathrm{e}}$ & $42.153 \pm 0.24^{\mathrm{e}}$ & $11.367 \pm 0.77^{\mathrm{a}}$ & $3.860 \pm 0.22^{\mathrm{c}}$ & $9.513 \pm 0.16^{\mathrm{ab}}$ & $28.970 \pm 0.22^{\mathrm{b}}$ \\
\hline unfermented & $3.310 \pm 0.16^{\mathrm{cd}}$ & $38.140 \pm 0.83^{\mathrm{d}}$ & $18.530 \pm 0.24^{\mathrm{b}}$ & $3.397 \pm 0.05^{\mathrm{b}}$ & $9.750 \pm 0.35^{\mathrm{b}}$ & $26.400 \pm 0.35^{\mathrm{a}}$ \\
\hline $\begin{array}{l}\text { Fermented } \\
\text { for 24 h }\end{array}$ & $3.023 \pm 0.08^{\mathrm{c}}$ & $26.667 \pm 0.29^{\mathrm{c}}$ & $18.293 \pm 0.21^{\mathrm{b}}$ & $3.147 \pm 0.07^{\mathrm{b}}$ & $8.877 \pm 0.09^{\mathrm{a}}$ & $39.117 \pm 0.31^{\mathrm{d}}$ \\
\hline $\begin{array}{l}\text { Fermented } \\
\text { for 48 h }\end{array}$ & $2.237 \pm 0.11^{\mathrm{b}}$ & $22.933 \pm 0.33^{\mathrm{b}}$ & $20.337 \pm 0.33^{\mathrm{c}}$ & $2.333 \pm 0.08^{\mathrm{a}}$ & $9.840 \pm 0.32^{\mathrm{b}}$ & $41.023 \pm 0.33^{\mathrm{e}}$ \\
\hline $\begin{array}{l}\text { Fermented } \\
\text { for 72 h }\end{array}$ & $1.800 \pm 0.15^{\mathrm{a}}$ & $21.927 \pm 0.52^{\mathrm{a}}$ & $22.367 \pm 0.21^{\mathrm{d}}$ & $2.123 \pm 0.13^{\mathrm{a}}$ & $11.620 \pm 0.31^{\mathrm{c}}$ & $38.633 \pm 0.26^{\mathrm{d}}$ \\
\hline $\begin{array}{l}\text { Fermented } \\
\text { for 96 h }\end{array}$ & $3.447 \pm 0.03^{\mathrm{d}}$ & $20.733 \pm 0.08^{\mathrm{a}}$ & $23.123 \pm 0.29^{\mathrm{d}}$ & $2.167 \pm 0.05^{\mathrm{a}}$ & $12.92 \pm 0.01^{\mathrm{d}}$ & $37.27 \pm 0.27^{\mathrm{c}}$ \\
\hline
\end{tabular}

**Values along the column are the means of triplicate determinations and those with the same superscript are not significantly different, at $\mathrm{P} \geq 0.05$.

Table 3: Mineral composition (mg/g) of raw and fermented Parkia biglobosa seeds

\begin{tabular}{|l|c|c|c|c|c|c|}
\hline Minerals & Raw seed & Unfermented & $\begin{array}{l}\mathbf{2 4} \mathbf{~ h} \\
\text { Fermentation }\end{array}$ & $\begin{array}{l}\mathbf{4 8 ~ h} \\
\text { Fermentation }\end{array}$ & $\begin{array}{l}\mathbf{7 2} \text { h } \\
\text { Fermentation }\end{array}$ & $\begin{array}{l}\mathbf{9 6} \mathbf{~ h} \\
\text { Fermentation }\end{array}$ \\
\hline Sodium & $17.00 \pm 0.10^{\mathrm{a}}$ & $30.10 \pm 0.15^{\mathrm{b}}$ & $31.5 \pm 1.47^{\mathrm{bc}}$ & $32.43 \pm 0.33^{\mathrm{cd}}$ & $33.23 \pm 0.88^{\mathrm{cd}}$ & $34.3 \pm 0.52^{\mathrm{d}}$ \\
\hline Potassium & $12.47 \pm 0.36^{\mathrm{a}}$ & $42.86 \pm 0.51^{\mathrm{b}}$ & $45.17 \pm 0.98^{\mathrm{bc}}$ & $47.83 \pm 0.31^{\mathrm{cd}}$ & $49.03 \pm 0.38^{\mathrm{d}}$ & $48.47 \pm 0.8^{\mathrm{cd}}$ \\
\hline Calcium & $54.47 \pm 0.16^{\mathrm{bc}}$ & $26.17 \pm 2.01^{\mathrm{a}}$ & $52.20 \pm 0.05^{\mathrm{b}}$ & $54.43 \pm 0.93^{\mathrm{bc}}$ & $55.7 \pm 0.05^{\mathrm{c}}$ & $50.83 \pm 0.8^{\mathrm{b}}$ \\
\hline Magnesium & $6.57 \pm 0.27^{\mathrm{a}}$ & $40.7 \pm 1.02^{\mathrm{b}}$ & $52.20 \pm 0.05^{\mathrm{bc}}$ & $54.43 \pm 0.93^{\mathrm{bc}}$ & $55.70 \pm 0.05^{\mathrm{c}}$ & $45.2 \pm 0.21^{\text {ed }}$ \\
\hline Zinc & $1.58 \pm 0.15^{\mathrm{c}}$ & $2.27 \pm 1.02^{\mathrm{d}}$ & $1.35 \pm 0.35^{\mathrm{bc}}$ & $1.25 \pm 0.04^{\mathrm{ab}}$ & $1.20 \pm 0.05^{\mathrm{a}}$ & $1.57 \pm 0.09^{\mathrm{bc}}$ \\
\hline Iron & $0.7 \pm 0.08^{\mathrm{a}}$ & $0.90 \pm 0.05^{\mathrm{a}}$ & $1.40 \pm 0.36^{\mathrm{b}}$ & $1.55 \pm 0.33^{\mathrm{b}}$ & $1.53 \pm 0.05^{\mathrm{b}}$ & $1.67 \pm 0.1^{\mathrm{b}}$ \\
\hline Lead & $0.23 \pm 0.05^{\mathrm{b}}$ & 0 & 0 & 0 & 0 & 0 \\
\hline Manganese & $0.97 \pm 0.14^{\mathrm{bc}}$ & $0.77 \pm 0.03^{\mathrm{a}}$ & $1.16 \pm 0.33^{\mathrm{b}}$ & $1.23 \pm 0.03^{\mathrm{b}}$ & $1.60 \pm 0.00^{\mathrm{c}}$ & $1.57 \pm 0.15^{\mathrm{c}}$ \\
\hline Cadmium & $3.97 \pm 0.88^{\mathrm{b}}$ & 0 & 0 & 0 & 0 & 0 \\
\hline Cobalt & $0.40 \pm 0.05^{\mathrm{b}}$ & 0 & 0 & 0 & 0 & 0 \\
\hline Nickel & $0.37 \pm 0.02^{\mathrm{b}}$ & 0 & 0 & 0 & 0 & 0 \\
\hline Phosphorus & $5.47 \pm 0.06^{\mathrm{a}}$ & $6.50 \pm 0.28^{\mathrm{b}}$ & $7.30 \pm 0.25^{\mathrm{c}}$ & $8.37 \pm 0.15^{\mathrm{d}}$ & $9.27 \pm 0.08^{\mathrm{e}}$ & $8.87 \pm 0.3^{\mathrm{de}}$ \\
\hline Copper & $0.72 \pm 0.03^{\mathrm{c}}$ & $0.40 \pm 0.04^{\mathrm{b}}$ & $0.45 \pm 0.33^{\mathrm{b}}$ & $0.47 \pm 0.29^{\mathrm{b}}$ & $0.00 \pm 0.00^{\mathrm{a}}$ & 0.00 \\
\hline
\end{tabular}

**Values in the row are the means of triplicate determinations and those with the same superscript are not significantly different, at $\mathrm{P} \geq 0.05$. 


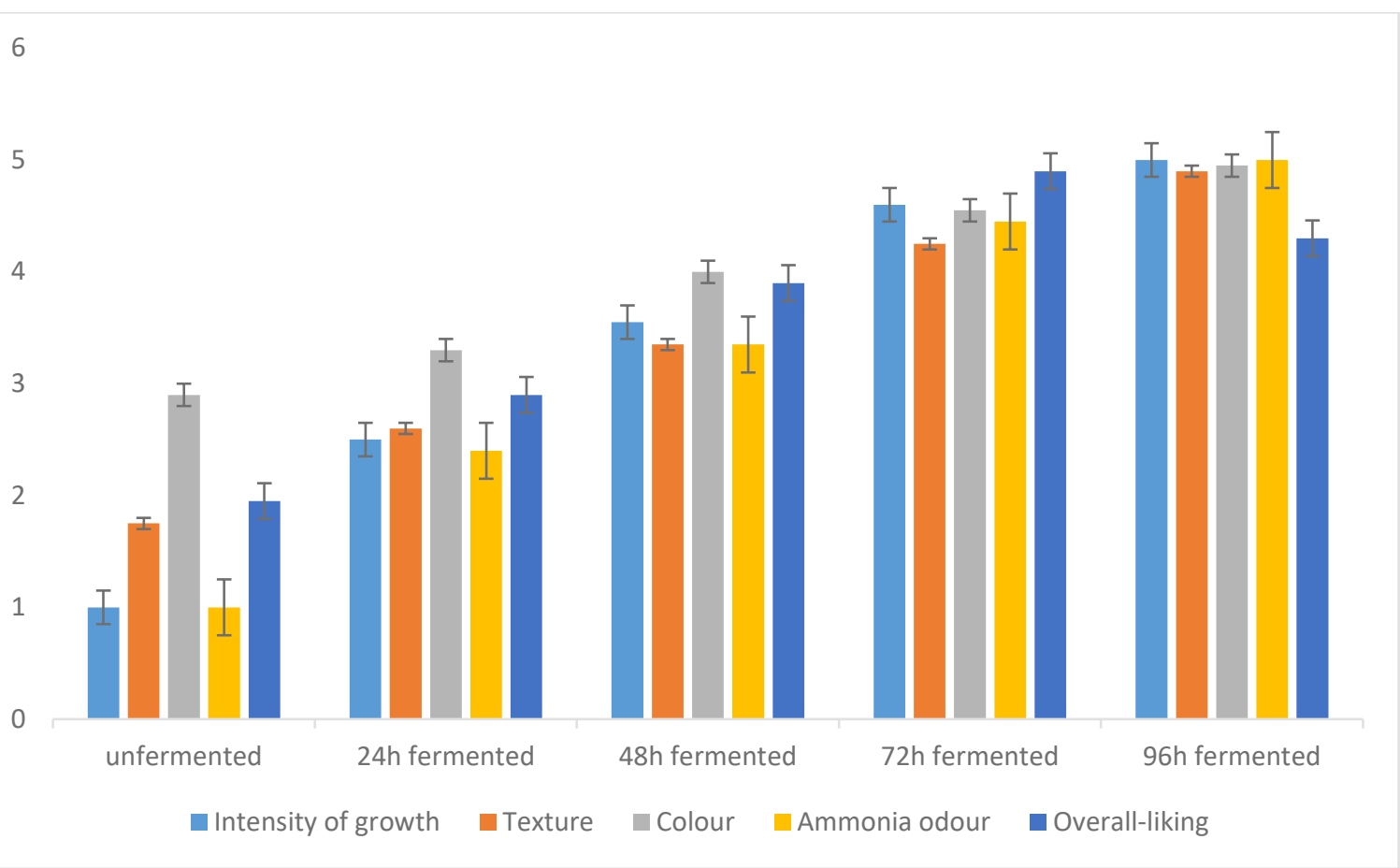

Figure 4: Sensory scores of Parkia biglobosa seeds fermented for different hours. Each value is the mean score of 30 panelists

\section{Discussion}

During the fermentation of Parkia biglobosa seeds, there was an increase in the bacterial load of the fermenting samples, the observed increase in the bacterial load during the fermentation is similar to the report of Adelekan and Nwadiuto [8]. The total bacterial count may have resulted from the ability of the first colonizing bacteria to degrade the more complex compound to simpler ones as the fermentation progressed [9]. Osho et al. [6] earlier reported the isolation of Lactobacillus and Bacillus subtilis from fermented Parkia biglobosa seeds while Leuconostoc sp was reported by Boateng et al. [10]. The bacterial load of the dehulled unfermented seed is lower than that of the raw seeds; this may have resulted from the heating effect of cooking on the vegetative bacterial cells.

The observed increase in the $\mathrm{pH}$ of the fermented samples may have resulted from the proteolytic activity of the fermenting bacteria as well as the release of ammonia as product of the breakdown of protein $[11,12]$. The decrease in titratable acidity and increase in $\mathrm{pH}$ in fermentation of Kpaya has also been reported [13], this decrease in the titratable acidity might have been the result of accumulation of ammonia and the increase in the $\mathrm{pH}$ of the fermented Parkia biglobosa seeds [4].

The increase in protein content and decrease in the carbohydrate during fermentation of $P$. biglobosa seeds is similar to the report of Makonjuola and Adebola, [1]. The proteolytic activity of the fermenting bacteria may have resulted in the increase in the protein content till $48 \mathrm{hr}$. The further decrease in protein after $48 \mathrm{hr}$ may have been the result of the utilization of the protein by the bacteria by eliciting degrading enzymes. The reduction in the carbohydrate may have resulted from the proliferation of the bacteria as they use it as the easiest source of energy for their growth and metabolism. Babalola and Giwa [14] reported a progressive decrease in the crude fiber of the fermented soy beans, the decrease may have resulted from the degradation of the dietary fiber present in the seed by the fermenting bacteria during fermentation. During fermentation of soy bean it was reported that there was an increase in the crude fiber as the fermentation progressed [14].

The heavy metals in the raw Parkia biglobosa seeds were no longer present after dehulling, this observation is similar to the report of Femi-Ola et al. [15]. These elements may be found on the coat of the seeds or may have been leached during boiling and washing [16].

The increase in the microbial intensity on the surface of the seeds correlates with the bacterial load. The bacteria load increased as the fermentation period progressed, this was also observed for 
the growth intensity on the surface of the beans. The change in the colour during fermentation was reported by Babalola and Giwa [14] when fermenting soy beans; a change in colour from butter to light Brown was reported and attributed to degradation of fat, protein and nucleic acid. Atere and Aderibigbe [4] recently reported that biochemical transformation alters the appearance, texture and flavour of fermented P. biglobosa seeds. The acceptability of the fermented Parkia seeds showed a significant acceptability as the fermentation progressed until a drop after $72 \mathrm{~h}$ of fermentation.

\section{Conclusion}

The time of fermentation has been shown to have some effect on the bacteria load, the $\mathrm{pH}$, titratable acidity, proximate, mineral and organoleptic characteristics of fermenting Parkia biglobosa seeds. The protein content increased from the onset of the fermentation until the peak was reached at $48 \mathrm{~h}$ and decreased. The overall-liking showed that panelists preferred samples fermented for $72 \mathrm{~h}$ to that of $96 \mathrm{~h}$ and others. This therefore indicate that optimum time of fermentation should be between $48 \mathrm{~h}$ and $72 \mathrm{~h}$ based on the nutritional content and the acceptability.

\section{References}

[1] Makanjuola, O. M and Adebola, A. Effect of natural fermentation on the nutritive value and mineral composition of African locust beans. Pakistan Journal of Nutrition 11 (1) (2012) 11-13.

[2] Haard, N.F., Odunfa, S.A. and Lee, C. Fermented Cereals. A Global Perspective. FAO Agricultural Bulletin No. 138. (1999) FAO Rome

[3] Campbell-Platt, G. African locust bean (Parkia species) and its West-African fermented food products, 'dawadawa'. Ecology of food and nutrition, (1980) 123-132.

[4] Atere, A. V and Aderibigbe, E. Y. Studies on the causative factors of odour development during fermentation of Parkia biglobosa. 2nd International Conference and Exhibition (OWSD-FUTA), (2015) 98-103.

[5] Odunfa, S. A. Biochemical changes in fermenting African locust bean (Parkia biglobosa) during 'iru' fermentation. Journal of Food Technology 20 (1985) 295-303

[6] Osho, A. I., Mabekoje, O. O. and Bello, O. O. Comparative study on the microbial load of Gari, Eluboisu and Iru in Nigeria. African Journal of Food Science 4(10) (2010) 646-649.

[7] AOAC. Official Methods of Analysis International. 18th Edition. Association of Official Analytical Chemists. (2005) USA.

[8] Adelekan, A. O. and Nwadiuto, E. Bacterial Succession Studies during Fermentation of African Locust Bean (Parkia biglobosa) to Iru Using Molecular Methods. British Biotechnology Journal 2(1) (2012) 49-59.

[9] David, O. M. and Aderibigbe, E. Y. Microbiology and proximate composition of 'ogiri', a pastry produced from different melon seeds. New York Science Journal 3(4) (2010) 18-27

[10] Boateng, M., Okai, D. B., Frimpong, O. Y. and Asabere, A. A comparative study of the nutritional and microbial profile of the processed seeds of the African Locust bean (Parkia biglobosa). Livestok Research for Rural Development Volume 26 (2014) 178.

[11] Omafuvbe, B. O, Shonukan, O. O. and Abiose, S. H. Microbiological and biochemical changes in the traditional fermentation of soybean for soy- daddawa -a Nigerian food condiment. Journal of Food Microbiology 17 (2000) 469- 474.

[12] Adeniran, H. A., Farinde, E. O. and Obatolu, V. A. Effect of heat treatment and fermentation on anti-nutrients content of Lima bean (Phaseolus lunatus) during production of daddawa analogue. Annual review and research in biology 3(3) (2013) 256-266. 
[13] Omafuvbe B. O, Abiose S. H, and Adaraloye, O. O. The production of Kpaye a fermented condiment from Prosopis africana (Guill and Perr) Taub. Seeds. International Journal of Food Microbiology 51 (1999)183-186.

[14]Babalola, R. O. and Giwa, E. O. Effect of fermentation on nutritional and anti-nutritional properties of fermenting Soy beans and the antagonistic effect of the fermenting organism on selected pathogens. International Research Journal of Microbiology 3(10) (2012) 333-338.

[15]Femi-Ola, T. O., Ajibade, V. A. and Afolabi, A. Chemical composition and Termicidal properties of Parkia biglobosa (Jack) Benth. Journal of biological Science 8(2) (2008) 494-497.

[16] Omafuvbe, B. O., Falade S. O., Osuntogun B. A. and Adewusi R. A. Chemical and biochemical changes in African locus beans (Pakia biglobosa) and melon (Citrullus vulgaris) seeds during Fermentation to Condiments. Pakistan Journal of Nutrition 3: (2004) 140-145. 